\title{
IMPACT OF E-BANKING ON SERVICE QUALITY AND CUSTOMER SATISFACTION IN SELECTED PRIVATE COMMERCIAL BANKS IN BANGLADESH
}

\author{
*Syed Nazmul Huda \\ ${ }^{* *}$ Sharmin Aktar \\ **** Mohammad Samiul Islam
}

Paper Received: 30.05.2020 / Paper Accepted: 30.06.2020 / Paper Published: 03.07.2020

\begin{abstract}
Background: Electronic banking (e-banking) is an important tool for all banks to survive in the competitive banking industry in Bangladesh. The study was designed to investigate the impact of online or e-banking in Bangladesh. There appear a few extensive studies on e-banking practices has been conducted in Bangladesh. But no comprehensive study has yet been conducted especially on impact of e-banking on service quality and customer satisfaction in Bangladesh. The main objectives of the study are to find out the impacts of e-banking products on service quality and customer satisfaction and access the challenges affecting e-banking.

Methods and Findings: The sample consisted of 379 out of 66895 client's feedback were selected purposively from various commercial banks in Bangladesh. Standard questionnaires and interview methods were made in collecting data. Descriptive statistics was adopted in analyzing the data from the respondents. In addition, for analyzing data suitable statistical tools Statistical Package for Social Science (SPSS) were used. The results revealed that there is a significant relationship between quality of service and customer satisfaction.

Conclusions: The paper concludes that e-banking has a positive impact on the quality of service in the Bangladesh banking sector, but not on customer satisfaction. The study suggests that staff training, and development should be enhanced in the banking industry in order to render quality and timely services to their customers.
\end{abstract}

Keywords: E-banking, Service quality, Customer satisfaction, Commercial banks, Bangladesh.

*Lecturer of Accounting, Bangamata Sheikh Fojilatunnesa Mujib Science \& Technology University, Jamalpur-2000, Bangladesh.

**Former Faculty, Department of Economics, Asian University of Bangladesh, Uttara, Dhaka-1230, Bangladesh.

***IRRI PhD Scholar at UPM and Assistant Professor, Department of Economics, Asian University of Bangladesh, Uttara, Dhaka-1230, Bangladesh.

\section{Introduction}

Online banking has influenced Bangladesh banking sector in a tremendous way. The application of bank products and services with the help of internet is called online banking. Integration of telecommunication instruments and tradition banking is called e-banking. Online banking has brought a great change in Bangladesh banking sector. Because of turbulent environment, Bangladeshi banks have been dynamic to meet this trend. The emergence of online banking has been making the banking practice easier since its conception in Bangladesh. The concept has moved Bangladeshi banks to a new height; they can compete favorably with another bank's world over. The banking industry believes that by adopting the new technology, Online banking, the banks will be able to improve customer service level and tie their customers closer to the bank. There are still some challenges of online banking in Bangladesh such as fraud, long waiting days for reversal of failed transactions, long queues and so on [1].

This study's objectives were-(i) to determine the effect of e-banking on customer satisfaction in selected banks of Bangladesh, (ii) to examine the effect of online banking products on service quality, customer satisfaction and (iii) to assess the challenges affecting e-banking [2]. Null Hypotheses were raised in line with the objectives of this research. There is no significant relationship between online banking, service quality delivery and customer satisfaction. E-payment remains the most widely used in the online banking solutions.

\section{Literature Review}

Some researchers conducted a study on online banking product and service in Bangladesh. Their findings showed that all the banks have at least one particular form of electronic service among ebanking service, online banking service and online banking [3]. Though various online banking systems have been implemented and accepted by the customer; e-payment remains the most widely 
used of the e-banking solutions in Bangladesh.

By comparing 32 elements of Banks's websites Suleiman et al conducted a similar case study on Malaysian Banking Sector finds that out of 53. \%, who used e-banking, $85 \%, 55.8 \%, 37 \%, 35.3 \%$, $30.8 \%$ used it for savings bank facility, current account facility, bill payment, visa /master card and third-party transfer respectively [3-6]. Generalization toward to general population isn't ethical in this case but it clearly indicates client's choice among e-banking services and users.

Ahmed and Islam in their study puts light on reasons for which banks in Bangladesh can develop strategies for expediting not only banking business but also providing customers' satisfaction. Business sector should be encouraged that make their own investment in the application of ICT in production, trade and services [7-9]. Prerequisite facilities funded by public private joint entrepreneurship using national resources and human resource improvement confine achievement of ICT policy's objectives.

Mohammed Sadique Khan et. al., in their study aimed at evaluating the service quality of internet banking services in India from customers perspective. For this a structured questionnaire containing 44 quality items was administered to various target groups. Seven quality dimensions like: reliability, accessibility , user-friendliness, privacy/ security, efficiency, responsiveness and fulfillment, were identified based on principal component factor analysis, A total number of 2500 mail ids were collected from the selected banks (public sector 1556, private sector 647 and foreign bank 297) for which only 1143 usable responses have been received, which is $46 \%$ of the total no. of email sent [10-13]. The study found that customers satisfied with quality of service on four dimensions such as reliability, accessibility, privacy/ security, responsiveness and fulfillment but least of them were satisfied with the user friendliness dimension. Finally, the study not only prioritizes different parameters but also provides guidelines to bankers to focus on the lacking area on which they need to improve [14].

Onyeukwu conducted case study in Nigeria. Eight banks with the sample size of 397 respondents were surveyed [15-18]. One-way ANOVA test was performed for checking the hypotheses. The study revealed that some Nigerian banks are not comprehensively training their staff because of its high cost. This has been hampering their employees' performance in the area of service delivery. Maximum client isn't pleased even after familiarization with e-banking [19].

\section{Bangladesh Perspective}

At present total 59 banks are operating in Bangladesh. Among them 10 banks are foreign. More than 40 private banks are in operation or approved. The monthly transaction in e-banking in BD is 87 crore USD. Around 14000000 mobile banking customers providing income of 29 million USD monthly.

Around 52 years ago USA based National City Bank of Network first introduced electronic fund transfer system toward to e-banking in 1961 at Bangladesh. The primary version of E-banking was introduced in 1981 by USA based four banks. After in 1983 UK based Bank of Scotland introduced first E-banking in the world. Successful and effective E-banking namely "net bank" established in 1996 but shut down in 2007. E-Commerce becomes popular by 2006 .

In 1994 Standard Chartered bank first introduced ATM service in BD. In 2004 AB bank, DutchBangla bank and Dhaka bank ltd. started internet banking. In e-banking Standard chattered banking is at top position. Only they provide American Express service. Trust bank ltd., Dutch Bangla bank ltd., Eastern Bank ltd., Dhaka bank ltd, prime bank ltd., Islami bank ltd, etc. are providing ebanking in BD. Among them Trust bank ltd., Dutch Bangla bank ltd., Eastern Bank ltd. Uses Fexcube software made by Iflix Solution. Trust bank ltd is using Flora bank software. According to Bangladesh Bank 10961 ATM booths are all over BD. $1408 \mathrm{CDM}$ and $258 \mathrm{CRM}$ machine is available also. The number of pause machine is 60474 in whole country [20].

In Bangladesh Till January 2020 credit number of credit and prepaid card customer is 18611681 and 428910 respectively. Most of the banks doesn't invest their $3 \%$ of total income to improve ebanking [21]. So, it is becoming a risky sector to hacking. They should introduce QR code, Block Chain technology, cyber security expert as soon as possible. According to central bank of Bangladesh 75294451 bank account $\mathrm{s}$ holding less than five thousand Taka now which is clear view of effect of Corona pandemic in Bangladesh.

\section{Methodology}

Survey design had been employed because the researcher seeks to obtain information from a cross-section of respondents comprising of different customers of different banks. The population of this study covers all the customers of the selected banks, namely, AB bank Limited, Trust Bank Limited, Dutch Bangla Bank Limited, NCC Bank Limited and Eastern Bank limited in Bangladesh. 


\begin{tabular}{|l|l|}
\hline \multicolumn{2}{|c|}{ Table 1: Sampled Bank's Customers' Strength } \\
\hline Bank & Customers' strength \\
\hline AB bank Limited & 15,835 \\
\hline Trust Bank Limited & 13,303 \\
\hline Dutch Bangla Bank Limited & 10,092 \\
\hline NCC Bank Limited & 14,936 \\
\hline Eastern Bank limited & 12,729 \\
\hline Total & 66,895 \\
\hline Source: Field Survey, 2020
\end{tabular}

Based on the above, it means 94 customers will be selected from AB bank Limited, 79 customers will be selected from the Trust Bank Limited, 60 customers will be selected from the Dutch Bangla Bank Limited, 89 customers will be selected from NCC Bank Limited and 76 customers will be selected from Eastern Bank limited. Sample size is 379. Graphical view of table 2 is provided in fig. 1

\section{Results and Discussion}

Table 2 shows feedback on online banking improved the quality of bank services. 84 (or $22.2 \%$ ) respondents strongly agreed to the statement, 114 (or $30.1 \%$ ) respondents agreed, 20 (or 5.3\%) respondents neither agreed nor disagreed, 118 (or $31.1 \%$ ) respondents disagreed and 43 (or
$11.3 \%$ ) respondents strongly disagreed. So, it can

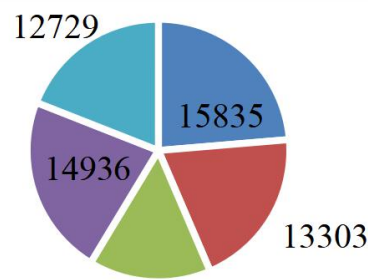

10092

- $\mathrm{AB} \quad$ Trust $\quad$ Dutch Bangla $\quad$ NCC $\quad$ Eastern

\section{Figure 1: Subjects of Banks}

be seen that maximum client are disagree on this said point. The chart above furthers help to provide deeper insights into the tabular presentation.

\begin{tabular}{|l|l|l|l|l|}
\hline \multicolumn{5}{|c|}{ Table 2: Online Banking has Improved the Quality of Bank Services } \\
\hline & Frequency & Percent & Valid Percent & Cumulative Percent \\
\hline Strongly Agreed & 84 & 22.2 & 22.2 & 22.2 \\
\hline Agreed & 114 & 30.1 & 30.1 & 52.2 \\
\hline Undecided & 20 & 5.3 & 5.3 & 57.5 \\
\hline Disagreed & 118 & 31.1 & 31.1 & 88.7 \\
\hline Strongly Disagreed & 43 & 11.3 & 11.3 & 100 \\
\hline Total & 379 & 100.0 & 100.0 & \\
\hline Source: Field Survey, 2020 \\
\hline
\end{tabular}

Table 3 depicts the response of obtained from the surveyed banks' customers on whether E-banking services provided by banks offer services according to the customer's needs and requirements. 83 (or $21.9 \%$ ) respondents strongly agreed to the statement, 91 (or 24.0\%) respondents agreed, 24 (or $6.3 \%$ ) respondents neither agreed nor disagreed, 88 (or 23.2\%) respondents disagreed and 93 (or
$24.5 \%$ ) respondents strongly disagreed. From the foregoing, the majority "strongly disagreed" that Ebanking services provided by banks offer services according to the customer's needs and requirements. The chart above furthers help to provide deeper insights into the tabular presentation.

\begin{tabular}{|l|l|l|l|l|}
\hline \multicolumn{6}{|c|}{ Table 3: The Online Banking Services Provide by Banks Offer Services According to The } \\
Customer's Needs and Requirements \\
\hline & Frequency & Percent & Valid Percent & Cumulative Percent \\
\hline Strongly Agreed & 83 & 21.9 & 21.9 & 21.9 \\
\hline Agreed & 91 & 24 & 24 & 45.9 \\
\hline Undecided & 24 & 6.3 & 6.3 & 52.2 \\
\hline Disagreed & 88 & 23.2 & 23.2 & 75.5 \\
\hline
\end{tabular}




\begin{tabular}{|l|l|l|l|l|}
\hline Strongly Disagreed & 93 & 24.5 & 24.5 & 100 \\
\hline Total & 379 & 100.0 & 100.0 & \\
\hline Source: Field Survey, 2020 \\
\hline
\end{tabular}

Table 4 represent feedback on inter dependence of Service quality and Customer's Satisfaction. 156 (or $41.2 \%$ ) respondents strongly agreed to the statement, 75 (or 19.8\%) respondents agreed, 33 (or $8.7 \%$ ) Respondents neither agreed nor disagreed, 69 (or 18.2\%) respondents disagreed, and 46 (or $12.1 \%$ ) respondents strongly disagreed. So, it can be seen that maximum client strongly agreed. The chart above furthers help to provide deeper insights into the tabular presentation.

Table 4: Online Banking Service Quality and Customer's Satisfaction are Inter-Dependent

\begin{tabular}{|l|l|l|l|l|}
\hline & Frequency & Percent & Valid Percent & Cumulative Percent \\
\hline Strongly Agreed & 156 & 41.2 & 41.2 & 41.2 \\
\hline Agreed & 75 & 19.8 & 19.8 & 60.9 \\
\hline Undecided & 33 & 8.7 & 8.7 & 69.7 \\
\hline Disagreed & 69 & 18.2 & 18.2 & 87.9 \\
\hline Strongly Disagreed & 46 & 12.1 & 12.1 & 100 \\
\hline Total & 379 & 100.0 & 100.0 & \\
\hline Source: Field Survey, 2020
\end{tabular}

Table 5 shows tabular view of feedback on Online Banking service quality in sample banks at present can improve customer's satisfaction significantly. 63 (or $16.6 \%$ ) respondents strongly agreed to the statement, 71 (or 18.7\%) respondents agreed, 25 (or 6.6\%) respondents neither agreed nor disagreed, 104 (or 27.4\%) respondents disagreed and 116 (or $30.6 \%$ ) respondents strongly disagreed. Maximum subject strongly disagreed on this point. The chart above furthers help to provide deeper insights into the tabular presentation.

\begin{tabular}{|l|l|l|l|l|}
\hline \multicolumn{5}{|c|}{ Table 5: Online Banking Service Quality in Sample Banks at Present can Improve Customer's } \\
Satisfaction Significantly \\
\hline & Frequency & Percent & Valid Percent & Cumulative Percent \\
\hline Strongly Agreed & 63 & 16.6 & 16.6 & 16.6 \\
\hline Agreed & 71 & 18.7 & 18.7 & 35.4 \\
\hline Undecided & 25 & 6.6 & 6.6 & 42 \\
\hline Disagreed & 104 & 27.4 & 27.4 & 69.4 \\
\hline Strongly Disagreed & 116 & 30.6 & 30.6 & 100 \\
\hline Total & 379 & 100.0 & 100.0 & \\
\hline Source: Field Survey, 2020 & \multicolumn{5}{|l}{} \\
\hline
\end{tabular}

\begin{tabular}{|l|l|l|l|l|}
\hline \multicolumn{5}{|c|}{ Table 6: The Adoption of Online Banking has Led to Improvement Customer's Satisfaction } \\
\hline & Frequency & Percent & Valid Percent & Cumulative Percent \\
\hline Strongly Agreed & 91 & 24 & 24 & 24 \\
\hline Agreed & 45 & 11.9 & 11.9 & 35.9 \\
\hline Undecided & 19 & 5.0 & 5.0 & 40.9 \\
\hline Disagreed & 95 & 25.1 & 25.1 & 66 \\
\hline Strongly Disagreed & 129 & 34 & 34 & 100 \\
\hline Total & 379 & 100.0 & 100.0 & \\
\hline
\end{tabular}




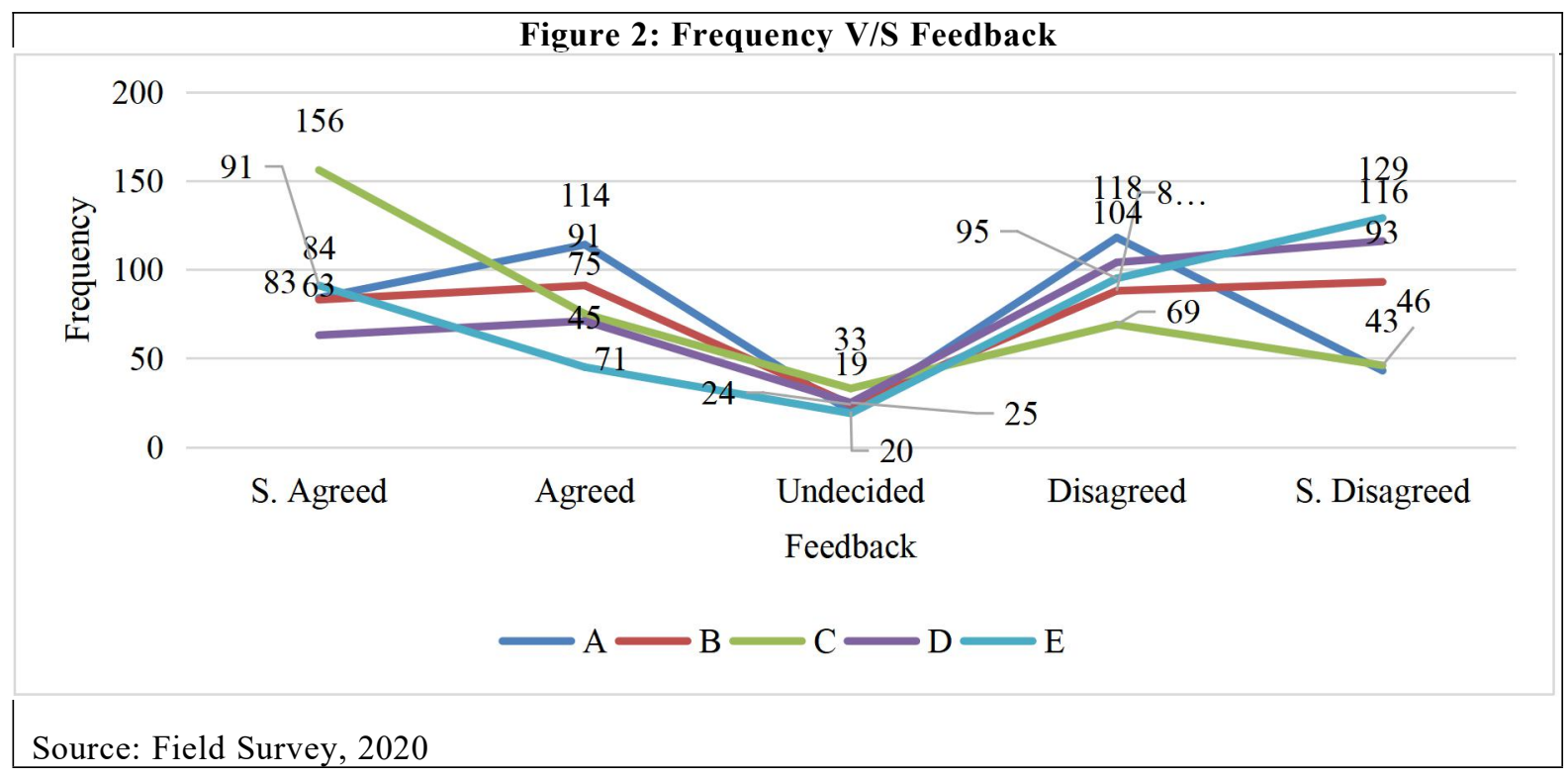

In fig $2 \mathrm{~A}, \mathrm{~B}, \mathrm{C}, \mathrm{D}, \mathrm{E}$ defines frequency of table $2,3,4,5,6$ respectively. Table 6 depicts the response of obtained from the surveyed banks' customers on whether the adoption of E-banking has led to improvement customer's satisfaction. 91 (or 24.0\%) respondents Strongly Agreed to the statement, 45 (or 11.9\%) respondents Agreed, 19 (or 5.0\%) respondents, 95 (or 25.1\%) respondents disagreed and 129 (or $34.0 \%$ ) respondents strongly disagreed. From the foregoing, the majority "strongly disagreed" that the adoption of E-banking has led to improvement customer's satisfaction. The chart above furthers help to provide deeper insights into the tabular presentation. Fig. 3 describes about cumulative percentage in different scenario of table $2,3,4,5,6$ respectively.

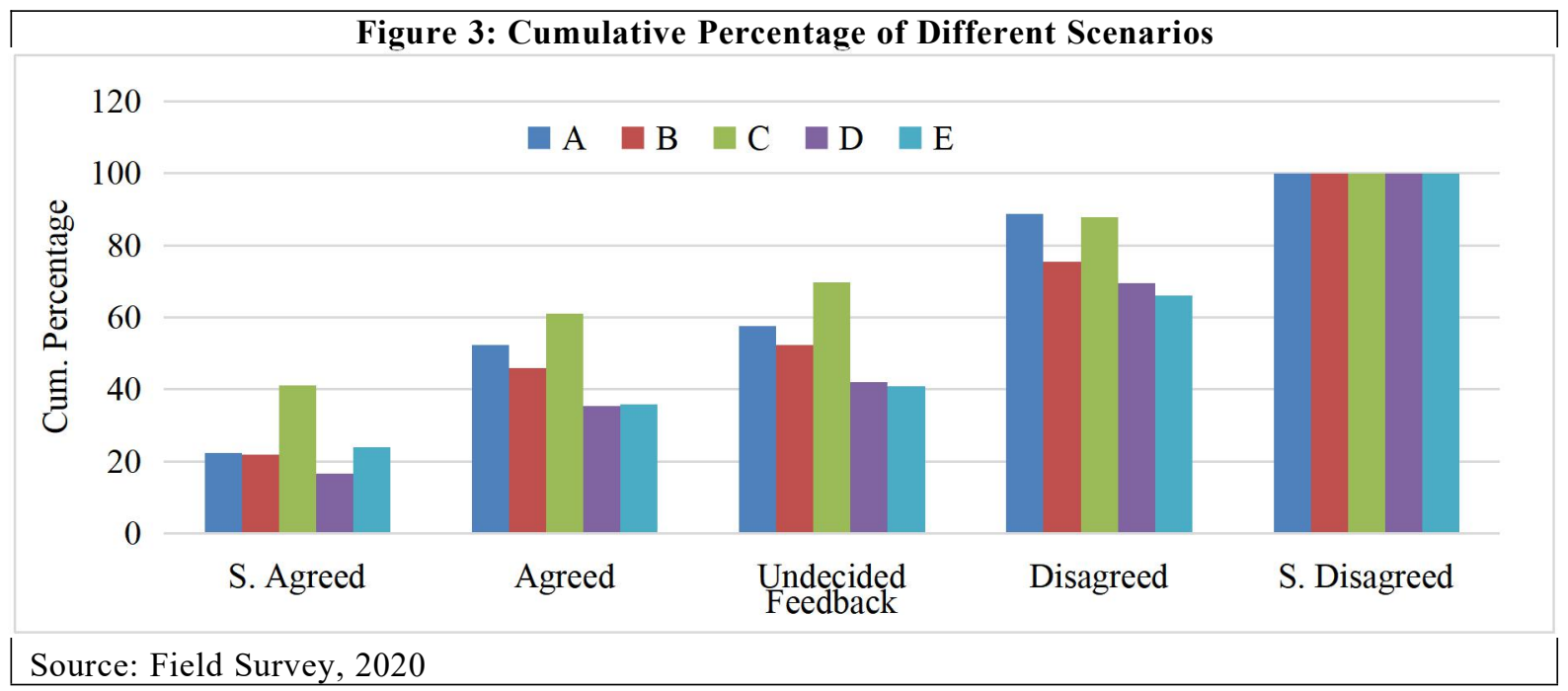

\section{Conclusions}

The third wave has brought a lot of changes world over; the banking industry has been benefiting greatly through its electronic banking and so on. Online banking has become the fundamental electronic distribution mechanism in today's banking business. Against all confront Banks are implementing auxiliary delivery channels to satisfy their clients. Thus, it can be said that online banking services have above all odds improved banking services; however, it is yet to have a significant effect on customers' satisfaction as evidence abounds on the daily challenges customers are going through with the use of any of the online banking products especially the Automated Teller Machine (ATM). This is why long queues have remained a feature of daily banking business in Bangladesh. Poor network service, insecurity, power failure amongst other issues are the reasons alluded by the customers to their dissatisfaction with the online banking service. 


\section{Recommendations}

In line with the research findings and conclusions, in this study suggests the following:

- The management of sample banks should put in more resources in staff training and development. This will help with quality and timely service delivery. Introduction to other products may please the client.

- Banks are advised to improve on their online banking products relentlessly. Upgrade their channels (such as ATM, MPOS, and POS) and enhance their software application (such as online application, e-mobile application) should be made where necessary so as to improve the quality of service delivered by them continuously.

- Finally, in order to eliminate challenges that customers face in the usage of online banking products, banks are advised to ensure stable power supply, ensure 24/7 network service availability, introduce block chain technology, maintain privacy, user friendly platform to ensure clients' satisfaction.

\section{Future Work}

The classification of bank customers using machine learning is under progress to provide effective suggestion regarding service quality and development of e-banking in Bangladesh.

\section{Acknowledgement}

This work was supported by IT division of Bangladesh Bank. Authors are very grateful to authority of AB bank Limited, Trust Bank Limited, Dutch Bangla Bank Limited, NCC Bank Limited, Eastern Bank Limited, respected customers and volunteers.

\section{References}

1. Alabar, T.T., (2012). "Electronic banking services and customer satisfaction in Nigerian banking industry". International Journal of Business and Management Tomorrow. 2(3): 18.

2. Adeyemi, O.A, Ola, O.S and Oyewole, F.A., (2014). "Internet Banking Functionality in Nigeria and Outcome of Customer Satisfaction": An Empirical Investigation. International Journal of Academic Research in Business and Social Sciences, 4(8a): 195-204.

3. Chavan, J. and Ahmad, F., (2013). "Factors Affecting on Customer Satisfaction in Retail Banking: An Empirical Study". International Journal of Business and Management Invention, 2(1): 55-62.

4. Dabbolkar, P.A., (1995). "A contingency framework for predicting causality between customer satisfaction and service quality". Advances in Consumer Research, 22(1), 101-
108.

5. Developed and Emerging Markets" Telematics and Informatics, 19, pp 315-330 Electronic Banking" Switzerland Bank for International Settlements.

6. Feroz, A. and Tarikul, M.I., (2008). "EBanking: Performance, Problems and Potentials in Bangladesh". Business Review, 06(1\&2).

7. Gbadeyan, R.A and Akinyosoye, O.O., (2011). "Customers' Preference for e-banking services": A case study of selected banks in sierra Leon. Journal of Business and Management Research, 1 (4), 108-116.

8. Investigation of the Level of Users' Acceptance of E-banking in Nigeria, Journal of Internet Banking and Commerce, 15(1).

9. Juran, J.M., (1988). Juran's quality Control handbook McGraw - Hill, New York, NY.

10. Kotler, P. and Keller, K.L., (2006). Marketing Management (Pp 402) New Delhi, India: Prentice - Hall.

11. McAlexander, J.H., Kaldenberg, D.O. and Koenig, H.F., (1994). Service quality measurement. Journal of Health Care Marketing, 14(3), 34-40.

12. Muniruddeen, L., (2007). "An Examination of Individual's Perceived Security and Privacy of the Internet in Malaysia and the Influence of This on Their Intention to Use E-Commerce": Using an Extension of the Technology Acceptance Model. Journal of Internet Banking and Commerce, 12(3).

13. Khan, M.S., Mahaptra, S.S. and Sreekumar, (2009). "Service Quality Evaluation Internet banking; An Empirical Study in India". International Journal of Indian Culture and Business Management, 2(1): 30-46.

14. Naik, C.N.K., Gantasala, S.B. and Prabhakar, G.V., (2010). "SERVQUAL, customer satisfaction and behavioural intentions in retailing”. European Journal of Social Sciences, 17(2), 200-213.

15. Okoro, A.S., (2014). "Impact of Electronic Banking Instruments on the Intermediation Efficiency of the Nigerian Economy". International Journal of Accounting Research, 1(6): 14-24.

16. Ojo, O., (2010). "The relationship between service quality and customer satisfaction in the telecommunication industry: evidence from Nigeria. BRAND. Broad Research in Accounting Negotiation and, Distribution, 1(1).

17. Oladejo, M. and Akanbi. T., (2012). "Bankers perceptions of electronic Banking in Nigeria: A review of post consolidation experience". Research Journal of Financial and Accounting. 3(2): 1-11.

18. Oni, Aderonke. A and Ayo, C.K., (2010). "An empirical Investigation of the level of users' 
Acceptance of E-Banking in Nigeria”. Journal of Internet Banking and Commerce, 15(1): 113.

19. Suleiman et al., (2005). "The Impact of Ebanking on Malaysian Banking Sector." African Journal of Business Management, 2(8): 2718-2727.

20. Mustafa, O., Turna, B. and Gulcin, (2020). "Website performances of commercial banks in turkey", Dumlupinar University Journal of Social Science / Dumlupinar Üniversitesi Soysyal Bilimler Dergisi. 64: 38-52.

21. Purwanto, A.M.D.C. and Faizah, R., (2020). "Utilization of E-Commerce And Aspects of Legal In Business Activities In The Village Prasung, District Buduran, Sidoarjo Regency”.
Veteran Society Journal, 1(1).

22. Agarwal, Nidhi and Pundir, Neelam, (2017). Information and Communication and its Importance. Ambikeya Journal of Education, 8 : 40-42, ISSN: 0975-9735.

23. Khursheed, Zeeshan and Parihar, R.S., (2019). Study of Data Mining and Trading in Indian EMarket. Globus An International Journal of Management and IT, 11(1): 24-27, doi: 10.46360/globus.120192004.

\section{Appendix A}

Questionnaire on e-banking or Online banking satisfaction levels regarding the various Services Quality Dimensions:

\begin{tabular}{|c|c|c|c|c|c|}
\hline & 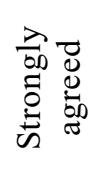 & $\begin{array}{l}\vec{D} \\
\stackrel{D}{0} \\
\stackrel{0}{0}\end{array}$ & 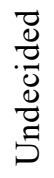 & 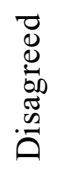 & 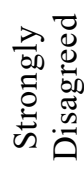 \\
\hline 1. Online banking has improved the quality of bank services & 5 & 4 & 3 & 2 & 1 \\
\hline $\begin{array}{l}\text { 2. The online banking services provide by banks offer services } \\
\text { according to the customer's needs and requirements }\end{array}$ & 5 & 4 & 3 & 2 & 1 \\
\hline $\begin{array}{l}\text { 3. Online banking Service quality and Customer's Satisfaction } \\
\text { are inter-dependent }\end{array}$ & 5 & 4 & 3 & 2 & 1 \\
\hline $\begin{array}{l}\text { 4. Online banking Service quality in Bangladesh banks at } \\
\text { present can improve customer's satisfaction significantly }\end{array}$ & 5 & 4 & 3 & 2 & 1 \\
\hline $\begin{array}{l}\text { 5. The adoption of online banking has led to improvement } \\
\text { customer's satisfaction }\end{array}$ & 5 & 4 & 3 & 2 & 1 \\
\hline
\end{tabular}

